\title{
How Did Sappho's Songs Get into the Male Sympotic Repertoire?
}

\author{
Ewen Bowie
}

It is as a performer on the barbitos - presumably accompanying the singing of her own songs - that Sappho is imagined by late sixth- and early fifth-century Attic vase painters, and was doubtless recognised by many Athenian sympotic users of these vases. ${ }^{1}$ The barbitos (as was shown by Yatromanolakis) is closely associated with comastic activity, and painters and their patrons seem to imagine Sappho in a context where she can chase (or be chased by, or perhaps both) an attractive young woman, ${ }^{2}$ or can find herself propositioned by an Alcaeus whose bashful down-turned gaze is in some tension with his clearly displayed penis. ${ }^{3}$ It must be conceded that the most common female musical performer in Attic representations of symposia and komoi is not a barbitos-player but an auletris, playing the aulos to accompany a male symposiast's singing. ${ }^{4}$ Likewise male are most of the figures who are shown holding a stringed instrument, whether a barbitos or a lyre, and singing to their own accompaniment. But both

1 Note the caution of Yatromanolakis (2007) 76 on whether the shape of the red-figure kalathoid vase of ca. 480-470 BC (Munich inv. no. 2416, his fig. 3a and 3 b) representing Sappho and Alcaeus is indeed sympotic. His argument, however, from the representation on the other side of the vase of Dionysus holding a kantharos and a female 'devotee' holding an oinochoe is strong; and one cannot question the sympotic function of the red-figure oinochoe representing a female figure holding a barbitos (Harvard Art Museum, inv. no. 1960.354) of ca. 490-48о BC (his fig. 2) or of the red-figure kalyx-krater representing Sappho with a barbitos (Bochum, Ruhr-Universität, Kunstsammlungen, inv. No. s 508) of ca. 480-470 BC (his fig. 4a). The barbitos is attested by Athenaeus 4.182e (= Sappho fr. 176) as an instrument mentioned by Sappho and has been supplemented in the last line of the new fragment pre- 58 yielded by

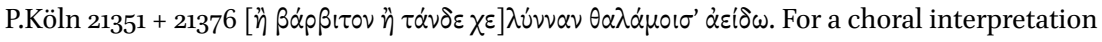
of the context of performance of the Tithonus poem see Bierl 2010.

2 Yatromanolakis (2007) fig. 4a, and for the label HE ПаIs fig. 7 .

3 Yatromanolakis (2007) fig. 3 a.

4 For the predominance of auletrides over players on the kithara or barbitos in the particular class of images involving 'Anacreontic' figures see Frontisi-Ducroux and Lissarrague (1990) 225 .

(C) EWEN BOWIE, 2016 | DOI: 10.1163/9789004314832_008

This is an open access chapter distributed under the terms of the Creative Commons AttributionNoncommercial 3.o Unported (CC-BY-NC 3.0) License. 
the aulos and a stringed instrument are regular providers of sympotic music, ${ }^{5}$ and several vases, including those just mentioned, suffice to show that the idea of a great female singer performing, accompanied on her barbitos, in a sympotic or comastic context was at the very least imaginable. ${ }^{6}$ That auletrides and young women dancers were regularly present at symposia will have made the introduction of a female virtuoso singer a small step, but it may be indicative of the higher status of a woman lyre- or barbitos-player that (so far as I have discovered) such players are never depicted naked, though several auletrides and a few lyre-playing youths are so portrayed. ${ }^{7}$

We do not, of course, know that symposia on Lesbos in the late seventh and early sixth centuries were like those depicted on later sixth-century Attic vases, though the presence of musical performances in symposia of that period is established for Mytilene by the poetry of Alcaeus and for Corinth by painted sympotic pottery, of which the earliest example is dated to the last quarter of the seventh century. ${ }^{8}$ We have no painted pots produced in Lesbos of the late seventh and early sixth centuries that depict symposia and that might support the hypothesis that elite symposia in Mytilene and other cities were indeed attended by hetairai, though recent excavations at Eresos have yielded a fragment of a middle Corinthian krater painted with a sympotic scene. ${ }^{9}$ That

5 Cf. Theognidea 533-534, and for lyre-playing male symposiasts see the red-figure krater Cleveland 26.549 $=A R V^{2} 563$ (9) (Lissarrague [1990] 12), the tondo of a red-figure cup Louvre $\mathrm{G} 127=A R V^{2} 427(1)$ (Lissarrague [1990] 35, fig. 21) and a red-figure cup Louvre G $245=A R V^{2}$ 366(86) (Lissarrague [1990] 35, fig. 22).

6 Note too the tondo of the red-figure cup attributed to the Pedieus painter (whose outside depicts an orgy of men in threesome and foursome coupling with naked hetairai), Louvre inv. No. G 13: a female lyre-player wearing an elaborate chiton is embraced by a youth holding a cup and a walking stick. Among 'Anacreontic' vases note (1) a red-figure krater in Vienna, Vienna 770, $C B$ II, no. 21, $A R V^{2} 576$ (33) representing a 'female kitharode' (so Frontisi-Ducroux and Lissarrague) between a male dancer and a male kylix-carrier, Frontisi-Ducroux and Lissarrague (1990) 225 with 250 fig. 7.28, and (2) a red-figure stamnos once in Rome, Cippico, now lost, Св II, no. 99, $A R V^{2}$ 291(25), which has a female barbitos-player flanked by two 'Anacreontic' figures on one side and a female cithara-player so flanked on the other, FrontisiDucroux and Lissarrague (1990) 225 with 250 fig. 7.29 (also registering in $\mathrm{n} .83$ a lone female barbitos-player on Munich 2317).

7 See Peschel (1987), Schäfer (1997) with numerous illustrations. Note however that in fourthcentury Athens the same two-drachma limit was applied to expenditure on auletrides, psaltrai and kitharistriai: Arist., Ath. Pol. 50.2.

8 An early Corinthian kotyle, British Museum inv. 73.8.20.387, Schäfer (1997) 25-35, Katalog II 1 (a) with Plate 2. 2 and 3 .

9 Zachos (2012) 309 with fig. 11, cf. Zachos (2010). I am grateful to Catherine Morgan for 
the local Lesbian pottery was initially a grey bucchero, and was almost never painted, and later in the archaic period a hard red ware, ${ }^{10}$ has deprived us of what might have been valuable testimony. It must also be remembered that the representation of hetairai on Attic pottery, especially on sympotic vases, only begins with the depiction of individual women's presence in the middle of the sixth century, and moves to the depiction of scenes, often orgiastic, with several participating hetairai, only in the last quarter of the sixth century.11 This iconographic evidence can be played in various ways. It can always be claimed that in the scenes on vases (as in the case of some of their grotesque Mischwesen) their painter's imagination ranges far from reality. ${ }^{12} \mathrm{But}$ other late-sixth-century evidence, such as the poetry of Anacreon, suggests there is some basis in real life. At the same time the relatively late appearance of hetairai in sympotic scenes on Attic vases cannot be pressed to insist that they were absent from pre-55о вс Attic symposia. ${ }^{13}$ Whichever position is taken on the evidentiary value of Attic pottery, we are still left groping in the dark concerning the place (or otherwise) of hetairai in elite symposia on Lesbos. ${ }^{14}$

One glimmer of light, however, comes to us from a much-discussed poem of Anacreon and from the Attic terms $\Lambda \varepsilon \sigma \beta i \zeta \varepsilon i \nu$ and $\Lambda \varepsilon \sigma \beta i \alpha \dot{\zeta} \varepsilon v$. The lines of Anacreon (fr. 358) in which the singer presents himself as incited by the cast of a dark-red ball by Eros to 'sport with' ( $\sigma \nu \mu \pi \alpha i \zeta g(v)$ a girl with fancy sandals, and as then rebuffed because of her pretentious Lesbian origin and his own advancing age, shows at the least that in Samian or Athenian symposia around the years $520-490 \mathrm{BC}$ there were (or could be imagined to be) Lesbian hetairai, and that they might occasionally claim an up-market status. The lines' conclusion may also indicate (though this is contested ground) that one of this girl's favoured sexual entertainments was fellatio. At least when a century later we first encounter the terms $\Lambda \varepsilon \sigma \beta i \zeta \varepsilon\llcorner\nu$ (in the future $\Lambda \varepsilon \sigma \beta เ \varepsilon i v$,

directing my attention to these articles. Slightly later (ca.540-520) an outdoor symposium is represented on the temple of Athena at Assos, an Aeolic settlement in the Troad, see Wescoat (2012): I am grateful to Vanessa Cazzato for this reference.

10 See Lamb (1932a) and (1932b), and note (1932b) 52 'amongst thousands of sherds only one shows traces of white paint'.

11 Reinsberg (1989) 104-112, Kurke (1999) 199-200 with further references n. 63 .

12 For scepticism about the relation between vase-scenes and sympotic reality, see Kurke (1999) 205-206, Topper (2012), esp. 136-161.

13 Reinsberg (1989) 108-114, Kurke (1999) 201.

14 A fragment attributed to Alcman (fr. 174) seems to attest komoi in late seventh century

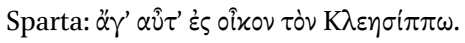


Aristophanes, Wasps 1346-1347) and $\Lambda \varepsilon \sigma \beta ı \dot{\alpha} \zeta \varepsilon v \nu$ (Aristophanes, Frogs 1308) they seem certainly to refer to fellatio. ${ }^{15}$

One thing, however, can and should be stressed. The archaic and classical hetaira could be a free citizen, ${ }^{16}$ and she could express her preference for association with one young man rather than with another. ${ }^{17}$ The Theodote of Xenophon's Memorabilia offers her favours only to those who persuade her and seems (together with her mother) very much in control of her life. ${ }^{18}$

One prominent component of the content of Sappho's songs was certainly eros, and the centrality of eros to male sympotic activity is documented beyond doubt by the later sixth century poetry of Theognis and Anacreon, by that of Pindar, and by scenes on sixth- and fifth-century Attic vases. What again is not so well-documented is the place of eros in late seventh-century Mytilenean symposia. A full text of Alcaeus would have had more amorous songs than have been preserved in quotation or happen so far to have turned up on papyri from Egypt - that is clear from Horace's reference to Alcaic love poetry about Lycum nigris oculis nigroque / crine decorum. ${ }^{19}$ But what survives falls short of linking eros and the symposium in the way we find in Anacreon, in Theognis 237-254 or in 'Book 2' of the Theognidea. Yet despite the known unknowns, I think it reasonable to put the sort of symposia of which we know from these poets and from vases together with the recurrent focus on eros in Sappho's songs and to hypothesise that she is singing for a male sympotic audience whose minds and bodies are so often directed to eros-whether that eros had as its object a young elite male or a young professional female-and that her self-presentation as a sexual agent who was also fired by desire for young females made an important contribution to raising the erotic temperature of male participants. The effect of Sappho's songs of

\footnotetext{
15 See MacDowell on Wasps 1346-1347 and Dover on Frogs 1308, with further literature.

16 Antiphanes fr. $210 \mathrm{~K}-\mathrm{A}$, cited by Kurke (1999) 185 n. 19.

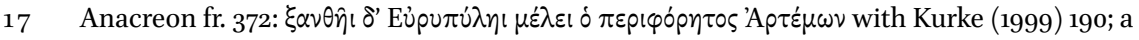
red-figure $p s y k t e r$, St Petersburg 644 (St. 1670) $=A R V^{2}$ 16(15) ca. 520 вС (Lissarrague [1990] 83 fig. 69) on which two naked women recline on cushions playing kottabos; one, called Smikra, says $\tau i \nu \tau \alpha \dot{\alpha} \nu \delta \varepsilon \lambda \alpha \tau \dot{\alpha} \sigma \sigma \omega, \Lambda \varepsilon \dot{\alpha} \alpha p \varepsilon$ ('I pitch this one for you, Leagros'); a red-figure hydria, Munich 2421 $=A R V^{2} 23(7)$ also ca. 520 BC (Lissarrague [1990] 83 fig. 70) on which two naked women reclining on cushions play kottabos, and the one on the left utters $\sigma o i$ $\tau \varepsilon v \delta i$ Evं $\theta u \mu \iota \delta \varepsilon \hat{\imath}$ ('[I throw] this one for you, Euthymides').

18 Xen. Mem. 3.11.

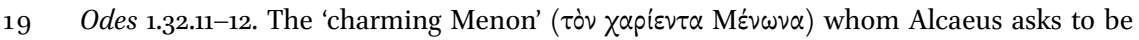
invited to a symposium at fr. 368 and the Damoanactidas of 296(b) seem also to be among

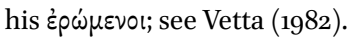


desire for young women, I suggest, may have been similar to that proposed by Leslie Kurke for the impact on male symposiasts of sympotic vases depicting sexually uninhibited symposia of naked hetairai: 'these vessels represent fantasies painted for the gaze of male symposiasts, who enjoyed seeing their own activities mirrored in those of sexually available female "companions" (often nude or semi-nude)' and (in relation to the hetaira represented as dedicating her kottabos throw to Euthymides) 'the hetairai on the hydria's shoulder are there to ventriloquize male desire: male symposiasts can savor the fantasy of a gathering of sexually active women sharing their longing for the beautiful Euthymides. And through their shared desire, the represented hetairai can stand metonymically for the eroticized sphere of the elite symposium generally' ${ }^{20}$

My title is intended to draw attention to how much easier such a hypothesis makes an attempted reconstruction of the movement of Sappho's songs into a male sympotic repertoire. There are of course other possible models. ${ }^{21}$ Those who believe that Sappho's songs of eros were composed for performance in a circle of female friends can suppose that Charaxos, when he was in town, could pass on the music and words of his sister's songs to his fellow symposiasts in Mytilene, or take some of them with him to Naucratis. ${ }^{22}$ Some similar mode of transmission could be imagined for a later generation. But that Sappho's songs were sung in male symposia ab initio avoids any objections that might be formulated to these other hypotheses.

Amongst these other hypotheses one of the most influential has been that of André Lardinois arguing in favour of 'public performance.' ${ }^{23}$ I suggest that many of his points are met by taking that 'public' performance to be one which took place in the restricted space of the symposium, a space both private and public. Thus the girls addressed by the singer are her fellow-entertainers, sometime, as he suggests, dancing. There are certainly a number of poems that he and others rightly see as marked by features of choral ritual performance: the hymenaia, and perhaps now in its augmented form fr. 17. But fr. 58.6

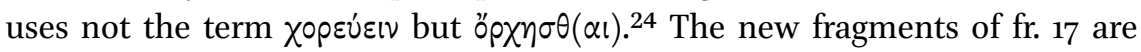
interpreted in the editio princeps as supporting the view that this poem was

\footnotetext{
$20 \quad$ Kurke (1999) 206. For the Euthymides hydria see above n. 17.

21 Cf. that proposed by Lardinois (2001).

22 The hypothesis of performance in a small circle of women is admirably argued against by Lardinois (1996) 154.

23 Lardinois (1996).

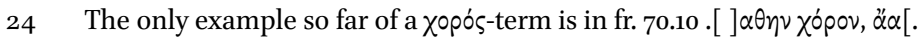


composed for choral performance, ${ }^{25}$ but a resolute sceptic might insist that it simply presented to a sympotic audience a re-creation of a choral, cultic song.

It might be asked whether the polis or its leading families would be comfortable with having a woman who sang to symposiasts to the music of her barbitos or lyra also play and sing for a chorus of women engaged in wedding rituals or cultic activities for Lesbian divinities. That is an unanswerable question, but in a later period and different cities we know that in a fourthcentury dramatic fiction a sympotic psaltria, Habrotonon, could be imagined as also playing for girls' choruses at the Tauropolia; ${ }^{26}$ that between 200 and $150 \mathrm{BC}$ a woman named Seddis was active as a kitharistria in a temple precinct in Sardis; ${ }^{27}$ and that it is possible that a kitharistria mentioned by Dinarchus in connection with the Eleusinia was actually playing in some festival ritual. 28

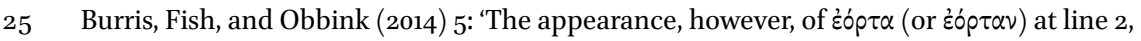
along with other new readings, indicates that the poem is not "personal" in theme, but is (or at least is presented as being) a choral song intended for cultic performance, as has already been suggested by Calame. The new first-person plural $\pi \dot{\eta} \eta \mu \varepsilon v$ at Fr. 2 ii 19

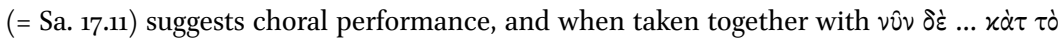
$\pi \dot{\alpha} \lambda[\alpha \circ v]$ the verb clearly announces a communal, cultic continuation of the preceding mythic material: "and now ... we act according to the old way." The make-up of the communal voice is probably indicated by the reference to "girls" and "women" at Sa. 17.1315, who together make up a joint chorus, assuming the supplement o"] $\chi \lambda$ os is correct (cf.

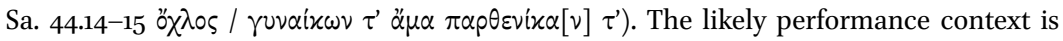
the temenos of the so-called "Lesbian triad", i.e. Zeus, Hera, and Dionysus, known from Alc. 129 and tentatively identified by Robert with the temple remains at Messa north of Pyrrha'.

26 Men. Epit. 477-479.

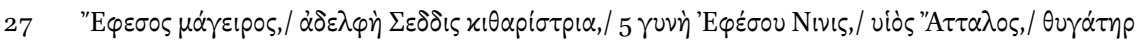

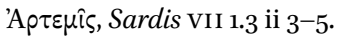

28 Dinarchus 1.23. That Themistius of Aphidna was executed for committing an act of hubris against this female kithara player (kitharistria) from Rhodes during Eleusinia can be taken as an indication that she might have been playing in the Mysteries, as it is by Power (2010) 365 n. 138. For the other cases see Power (2010) 6o n. 136. The question of whether certain female performers on stringed instruments in the Hellenistic period are properly termed kitharoidoi, the subject of an animated discussion by Goldhill (2005), is only marginally relevant to my subject here. 


\section{Some Test Cases}

Before turning to the 'Brothers Poem' I offer some brief sketches of how some long-known poems or fragments might be read in the light of the hypothesis of a chiefly male sympotic audience.

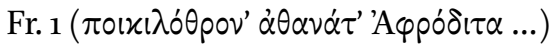

On my hypothesis this would be a sympotic prayer of the sort we find in the Theognidea 1-22 or in Anacreon fr. $357,{ }^{29}$ a song in the form of a prayer addressed to a god whose sphere includes the activities of the symposium. The male audience may or may not suppose that the object of the singer's desire is one of the girls who, like the singer, are performing at the symposium-playing the aulos, dancing, or showing off her physical attractions or acrobatic skills;

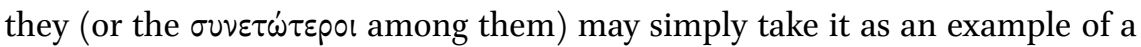
song that could be sung by one young woman infatuated with another. Either way it can kindle or feed their own fires of passion for a youthful love-object, whether male or female.

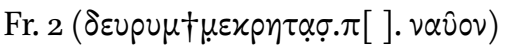

Although this song is as strong a candidate as any for first performance in a ritual space, the vivid evocation of that space in the first three stanzas becomes much harder to interpret as relating precisely to the context in which it is being sung when we reach the fourth stanza:

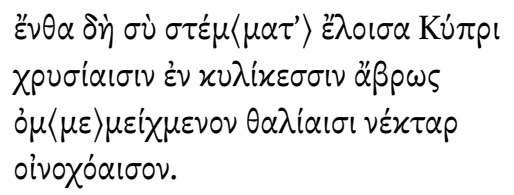

In this place, Cypris, take the garlands and delicately in golden cups wine-pour the nectar that has been mixed for banquets.

If this is a hymn accompanying a ritual act, what can Aphrodite do that will count as 'taking' the garlands? 'Taking' is quite different from the normal rit-

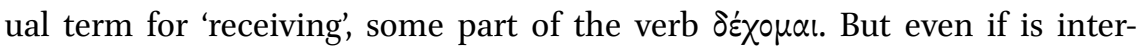

$29 \hat{\omega} \nu \alpha \xi, \hat{\omega} \iota ~ \delta \alpha \mu \alpha \lambda \lambda \varsigma$ ” E $\rho \omega \varsigma$... ('Lord, with whom Eros the subduer ...') discussed in Bowie (2012). 
preted as an untypical way of singing about such divine acceptance, what will Aphrodite do that can be described as 'wine-pouring nectar in golden cups'? This stanza undermines any literalist interpretation and brings the imaginary locus amoenus of the sacred grove into the sympotic performance space where wine, cups and oinochooi are in plentiful supply: were Aphrodite to come and pour liquid into the symposiasts' cups, that liquid would inevitably be nectar, as it is in what seems to be a memory of the first-person speaker of fr. 96.2628 , the memory of an occasion whose nature is irrecoverable as a result of the tattered state of the papyrus. ${ }^{30}$

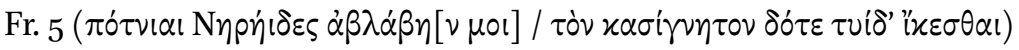
Like frs. 1 and 2, I suggest that this is a sympotic prayer, and that Sappho can rely on her male sympotic audience knowing who Charaxos is, why he is in Egypt, and what reasons Sappho has for praying for his safe return. Her mention of $\varphi$ i $\lambda$ or and ${ }^{\prime} \chi \chi \theta p o r$ taps into a recurrent theme of male sympotic song, amply attested in the iambic poetry of Archilochus, the melic poetry of Alcaeus and the elegiac poetry of Theognis, though it is of course widespread in almost all genres of archaic and classical Greek literature.

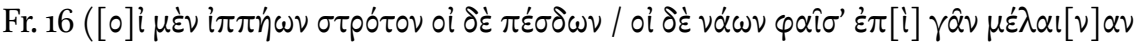

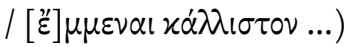

Like fr. 1, this song prompts reflection on eros, but Sappho moves to that through a range of very masculine hypothetical answers to the question 'What

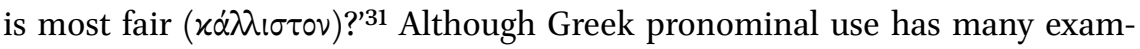
ples of 'masculine' for 'feminine', here the successive oi $\mu \dot{\varepsilon} v$... oi $\delta \dot{\varepsilon}$, and oi $\delta \dot{\varepsilon}$ ('some ... some ... some ...'), when interpreted against these o's canvassing of cavalry, infantry and ships, are easiest to take as genuine masculines: Sappho starts her investigation from the foil of a male perspective. It may also be a male perspective that explains her decision to pick out the pre-eminent beauty of Helen. As has often been remarked, Helen's beauty is not relevant to the point that she left the best of husbands, her daughter and her parents because of eros. But it brings home to men who may each think himself the best of husbands the danger of losing the woman who for him has been out-

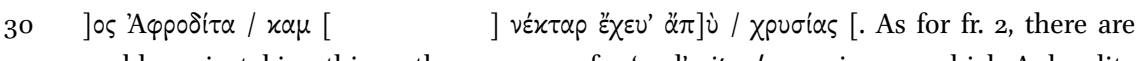
problems in taking this as the memory of a 'real' ritual occasion on which Aphrodite was herself present and the liquid that was poured into golden (? cups) was 'really' nectar.

31 Cf. Theognidea $255^{-256}$, the epigramma Deliacum. Among many discussions see especially Bierl (2003). 
standingly attractive-a danger whose realisation is followed up by Sappho's surprising shift of focus to longing felt by an abandoned lover for a departed love-object.

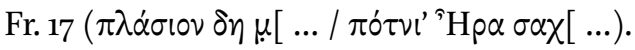

As I have already said, the newly augmented text of this poem makes it a strong candidate for ritual performance. But the text remains too lacunose to clinch the matter, and a sympotic prayer which evoked cultic activity at the temenos of Hera, Zeus and Dionysus at Messon remains a possible interpretation.

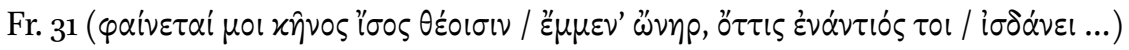
The presence in the same space of a man and the young woman who arouses Sappho's passionate physical reactions has always been a problem for hypotheses that Sappho's first audiences were a circle of such young women, and the solution offered by Wilamowitz's 'bridegroom' hypothesis now has few if any takers. Interpretation becomes easier if we envisage Sappho singing this song accompanying herself on her barbitos in a sympotic space where youths and hetairai sit or recline on the same seats or couches. The hetaira is doing what a hetaira is expected to do-chatter, perhaps sing, and laugh in a seductive way. We are not told if she is standing, sitting or reclining. That the man is sitting (i $\sigma \delta \alpha \dot{\alpha} v \iota)$, not reclining, differentiates him from most men in Attic and Corinthian sympotic vase scenes. But we do not know how uniformly the oriental habit of reclining was adopted in archaic Greek poleis. It may be attested around 650 BC for Ephesus by the term $\varkappa \alpha \tau \alpha \varkappa \varepsilon i \tilde{\sigma} \theta \varepsilon$ ('lie back') in Callinus fr. 1.1, and for Thasos or Paros by $x \varepsilon x \lambda$ « $\mu \varepsilon$ vos ('leaning' or 'reclining') in Archilochus fr. 2.2. Alcman fr. 19.1 attests seven $x \lambda$ ival in what seems to be the description of a symposium, presumably but not certainly in Sparta, but we have to wait for Dionysius Chalcus fr. 3.5 in late fifth-century Athens before we find a $x \lambda i v \eta$ in a sympotic elegy. It could be argued that if Alcaeus refers to a 'soft pillow', $\mu \dot{o} \lambda \theta \alpha x \circ v$... rvó $\varphi \alpha \lambda \lambda \circ v$, at fr. 338.8 , then he imagines himself reclining. But that is not certainly the meaning of yvó $\varphi \alpha \lambda$ ov —in his 1982 Loeb Campbell had moved from his 1967 translation 'cushion' to the quite different rendering 'fillet' 32 - and to the best of my knowledge no excavation of an andron so shaped as to accommodate $x \lambda i v \alpha$, , 'couches', has established that when Alcaeus had a symposium in Mytilene with his hetairoi they are likely always to have reclined.

32 Campbell (1982a) 375 'put a soft fillet round your brows'. 


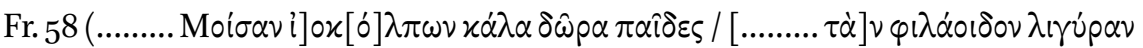
$\left.\chi \varepsilon \lambda u^{\prime} v \alpha \alpha\right)$

This is one of very few poems in which we find both Sappho and a plurality of girls. Unfortunately even after the new papyrus, its lacunose first lines leave us uncertain what relation the song set out between the 'fair gifts of the violet-

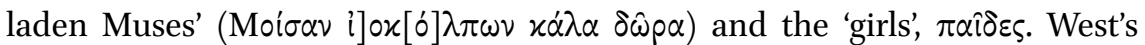
supplement at the beginning of line 1 of $u_{\mu \mu} \mu \varepsilon \varsigma \pi \varepsilon \delta \dot{\alpha}$ and at the beginning of the

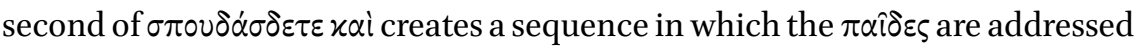
with a command in the second line, encouraging the supposition that Sappho may be acting as some sort of choragos. But there are other possibilities, e.g.

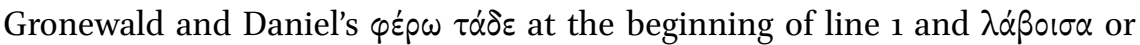
$\varepsilon^{2} \lambda \circ เ \sigma \alpha \pi \dot{\alpha} \lambda \iota v$ at the beginning of line 2: these supplements would reduce the role of the girls to no more than an audience. They may be implicitly an audience that, unlike the singer as represented in her sad song, is still young enough to dance, but this dancing could as well be sympotic entertainment for men as choral ritual: note the point made above that the term used here for dancing

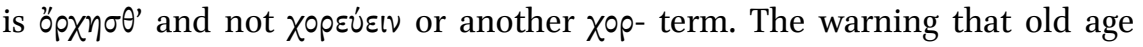
inevitably succeeds youth was a sympotic theme favoured by Mimnermus (e.g. fr. 1, fr. 2, and fr. 5) and Anacreon (e.g. fr. 395) and one highly relevant to the life of the pleasures of wine, women (and boys) and song chosen and celebrated by symposiasts.

Frs. 94 and 96: like fr. 1 and fr. 31, these songs will have turned male symposiasts' thoughts to the pains and pleasures of eros - the pain of parting which could be occasioned by the sort of mercantile adventures that, as the evidence from Naucratis shows, Charaxos was not alone among Mytileneans in undertaking; the pleasures of memory; and the association of some of these pleasures with sympotic accessories - perfume, garlands, and soft beds or cushions of the sort on which, at least on some Attic vases, drinkers are depicted as reclining.

\section{The Brothers Poem}

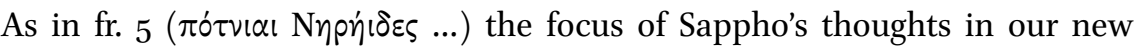
poem is her brother Charaxos, a man perhaps more likely to be well-known to male symposiasts than to a circle of choreutic parthenoi. But who is the addressee? I do not want to spend time bringing arguments against other scholars' proposals, but shall rather raise what seems to me a problem with the text as it is presented by the new papyrus.

Ever since Dirk Obbink released his preliminary publication I have been unhappy about the sense proposed for lines $7^{-13}\left(3^{-9}\right)$ : 


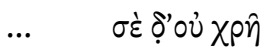

$\tau \alpha \hat{\tau} \alpha$ vó $\sigma \theta \alpha$,

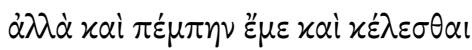

10

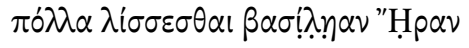

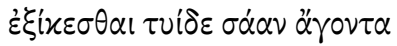

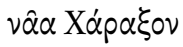

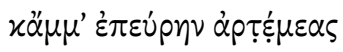

These lines he translated as follows: ${ }^{33}$

But it is not necessary

for you to think these things,

but especially to send me and command to beseech

Queen Hera over and over again

that Charaxos may arrive, piloting

his ship safe back here

and find us safe and sound.

Cf. Rayor's translation in Rayor and Lardinois (2014) 16o:

Don't think about that,

but send me, yes command me

to keep praying to Queen Hera

that Charaxos return here

guiding his ship safely.

and find us secure.

This is an oddly indirect way of the singer suggesting that she herself should go to pray for her brother's return, oddly oblique concerning where the singer is being sent, and odd too in the overlap in sense of 'send' and 'command', perhaps responsible for Rayor's rendering 'send me, yes command me' (which seems to

33 Obbink (2014b) 39-40. 
betray a degree of discomfort). The parallel offered from Iliad 6.269-279 34 is not at all close and involves a simpler sequence. In the Iliad Hector (a male relative) asks Hecuba (a female relative) to gather the old women of Troy and go to the temple of Athena to make an offering (of a peplos) and a vow (to sacrifice twelve oxen if she takes pity on the Trojans); in the papyrus text of the Sappho poem the singer tells an addressee (supposed by some to be a female relative) to tell her to supplicate Hera with the request that Charaxos (her male relative) return safely. In Sappho's poem there is neither offering nor vow; in the lliad the term 'supplicate' ( $\lambda$ i $\sigma \sigma \varepsilon \sigma \theta \alpha \iota)$ is not used.

Bearing in mind that the scribes of papyri regularly make mistakes, I offer a tiny conjecture—we should read है $\mu \alpha$ ('my things') in place of है $\tilde{\mu} \mu \varepsilon$ ('me'):

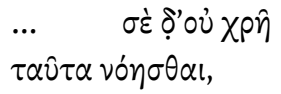

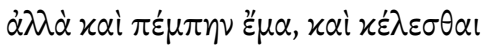

10

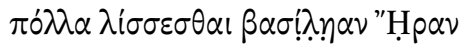

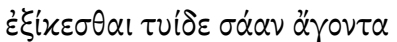

$\nu \hat{\alpha} \alpha \mathrm{X} \alpha \dot{\rho} \alpha \xi \circ \nu$

Don't you think of that,

but both send my stuff, and tell

Charaxos to make many supplications to queen Hera,

that he should arrive here bringing his ship safely.

Sappho's है $\mu \alpha$ are not difficult to cash out as the fuller phrases she may know from the Odyssey or from lost epic poetry that deployed the same or similar

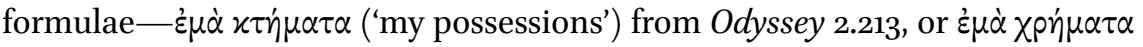
('my resources') from Odyssey 13.283. And although in Homer $\pi \dot{\varepsilon} \mu \pi \varepsilon v \nu$ ('to send') usually has a person as its object, there are exceptions. Thus at Odyssey 16.83

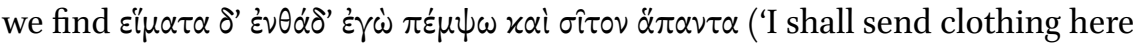
and all the food he needs'). Then, in a seventh-century poem that seems to have quite close links with Lesbian poetry, the Homeric Hymn to Aphrodite, the precious objects that Aphrodite feigns will be sent as her dowry to Anchises: of

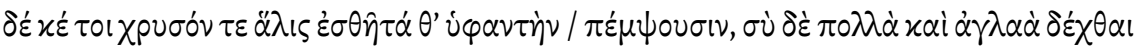
$\dot{\alpha} \pi \circ v \alpha$ ('And they will send you in ample quantities gold and woven garments, and you will receive a large and brilliant dowry', 139-140).

34 A suggestion of Joel Lidov kindly communicated to me by André Lardinois. 
It might be objected that not $\tilde{\varepsilon} \mu \alpha$ but $\tau \dot{\alpha} \tilde{\varepsilon} \mu \alpha$ would be expected. Against that objection I make two points. First, it is well established that the article is used much less, and in many respects differently, in the Lesbian Aeolic of Alcaeus and Sappho by comparison with Attic and Ionic. In the particular case of pos-

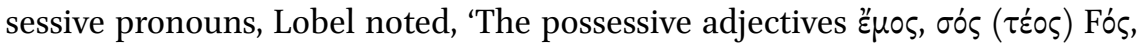

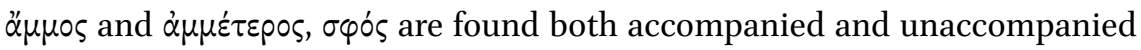
by the definite article ... ${ }^{35}$

Second, there are parallels in other poetry:

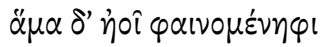

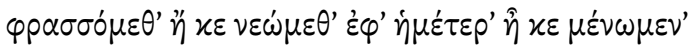

Il. $9.618-619$

And at the time when dawn displays herself

we shall ponder whether we are going to go to our home or to stay.

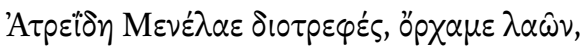

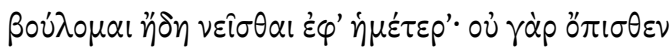

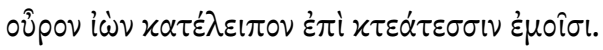

Od. $15.87-89$

Menelaus, son of Atreus, nurtured by Zeus, marshall of peoples, I now wish to go to our own place: for when I came

I did not leave behind a watcher over my possessions.

In both these Homeric passages the audience supplies a noun with the neuter

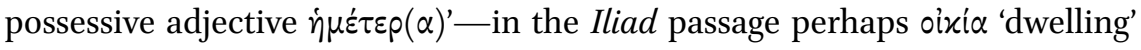
(as in Iliad 6.15 etc.) or $\delta \omega \mu \alpha \tau \alpha$ (as in Odyssey 3.355, 8.31, 8.41); in the Odyssey passage either oixí or $\delta \omega^{\prime} \mu \alpha \tau \alpha$ or (slightly differently) $\varkappa \tau \eta^{\prime} \mu \alpha \tau \alpha$ or $\varkappa \tau \varepsilon \alpha \tau \alpha$ (cf.

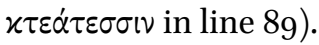

If this change is accepted, it is hard not to think that the addressee of this song, sung to men in Mytilene who knew Charaxos, was none other than the absent hetaira Doricha of Naucratis, on whom Charaxos spent loads of money, ${ }^{36}$ and whom Sappho attacked in fr. 15. It also seems likely that the $\mu \mathrm{\nu}$ whom Herodotus recalls a melos of Sappho as having abused (admittedly in

36 Ath. 13.598b-c cf. POxy. 1800 col. i 7-13 (both = fr. 202). 
a discussion that confuses Doricha with Rhodopis) is not Charaxos himself but the hetaira, as has been well argued by Maria Kazanskaya in a recent paper. ${ }^{37}$ In our poem Sappho sings of a situation-either real, or a mixture of reality and imagination - in which Doricha is represented as sending repeated reassurances that Charaxos will return with a fully-loaded ship; but that has not actually happened, and Sappho here urges Doricha to send Charaxos on his way home and to tell Charaxos to pray for a safe return at a temple of Herapresumably the one at Naucratis mentioned by Herodotus and identified by excavators on the basis of inscriptions on sixth-century pottery, several of them marking dedications by Mytileneans. ${ }^{38}$ On this interpretation the first-person

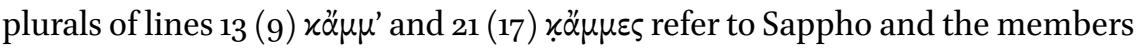
of her family who have remained on Lesbos-certainly Larichos, perhaps the third brother Erigyios. What metaphorical storm has threatened that family we can only guess - something that presumably threatened Sappho's own station in Mytilenean society-but it is one whose replacement by (metaphorical) plain sailing Sappho hopes will be secured by the return of Charaxos, already, perhaps for some years, a man, and by a hitherto unseen readiness to be selfassertive on the part of the still immature Larichos.

What was the stuff, the $\varepsilon^{\prime \prime} \mu \alpha$, that Sappho expected from Naucratis? In 1964 John Boardman guessed the things archaic Greeks got from Naucratis were corn, papyrus and linen. ${ }^{39}$ But it was only an educated guess. ${ }^{40} \mathrm{I}$ have consulted

Hdt 2.135, discussed by Kazanskaya forthcoming. In favour of the traditional interpretation, see Lardinois in this volume.

38 Hdt. 2.178.3. For the inscriptions from the temenos of Hera, see Gardner (1888) 67, nos. 841844, and for those from the temenos of Aphrodite Gardner (1888) 63-67 nos. 701-882, including inscriptions in Aeolic on grey bucchero, Gardner (1888) 65 nos. 786-793, Möller (2000) 259-26o. Some corroboration of Herodotus' story comes from a dedication by Archedice (cf. Hdt. 2. 135.5), cf. ABSA 5 (1898-1899) 56 no. 108, illustrated by Möller (200o) fig. 3d.

39 Boardman (1980) 129-133 at p. 129 (a revised and enlarged edition of the book which first appeared in 1964). For Naucratis' trading role, see Möller 2000. For the fifth century вС Hermippus, Phormophoroi fr. 63.12-13 PCG (quoted by Athenaeus 1.27-28) attests sails and

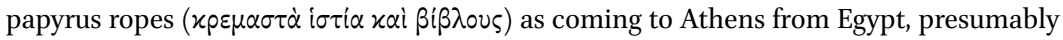
but (by this date) not certainly via Naucratis (see Raaflaub in this volume n. 43).

For corn from Egypt in the early to mid fifth century see Bacchylides fr. 2ob Maehler. That linen was to be had, and perhaps was worked, in Naucratis, at least in the third century BC, was later shown by Posidippus 36 А.--в., a girl's dedication to Arsinoe-Aphrodite (see

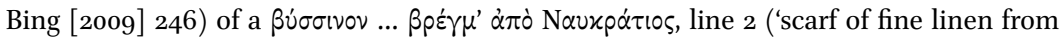
Naucratis', transl. C. Austin). It is tempting to think that the idea that the dead and deified Arsinoe wants the scarf 'to wipe off the sweet perspiration when she has ceased from her 
one of the leaders of the international Naucratis project, Alan Johnston, and he replied: 'Not an enormous amount known. There are trinkets of various kinds, and the Berlin palimpsest of probably $475 \mathrm{BC}$ gives only natron as an outgoing cargo'.41

That natron is documented is not without interest. I quote Wikipedia:

... natron was harvested directly as a salt mixture from dry lake beds in Ancient Egypt and has been used for thousands of years as a cleaning product for both the home and body. Blended with oil, it was an early form of soap. It softens water while removing oil and grease. Undiluted, natron was a cleanser for the teeth and an early mouthwash. The mineral was mixed into early antiseptics for wounds and minor cuts. Natron can be used to dry and preserve fish and meat. It was also an ancient household insecticide, was used for making leather and as a bleach for clothing.

For Sappho, then, natron could be used both to wash herself and her clothes, something to which any high-class performer, including singers and hetairai, would — or should — attach some importance. It was also used to wash drinking vessels, $\dot{\varepsilon} x \pi \omega^{\prime} \mu \alpha \tau \alpha{ }^{42}$ And fish-preservation, still important to the twentiethcentury economy of Ayvalık/Kydonia in the Mytilenean peraia, might be a useful component of whatever local services other than sympotic entertainment Sappho and her brothers were providing. Finally its application in leathermaking would not be irrelevant to the production of o' $\lambda ı \sigma \beta o$, 'dildoes', which may be mentioned by Sappho. ${ }^{43}$

Not surprisingly, then, the second-century lexicographer Phrynichus attests the mention of natron/vitpov by Sappho: ${ }^{44}$

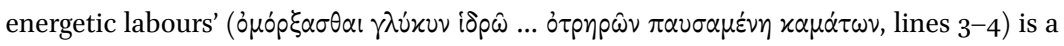
cheeky reworking of a lost Sapphic reference to such material in an erotic context (cf.

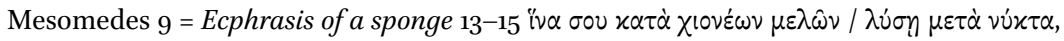

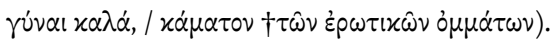

41 For a text and thorough discussion of the Elephantine papyrus see Yardeni (1994): I am grateful to Peter Haarer for directing me to this publication.

Alexis fr. 2 K.-A. = Ath. $11.502 \mathrm{f}$.

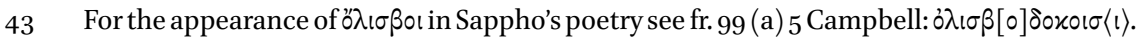
As the editors point out to me, however, this papyrus fragment was assigned to Alcaeus by

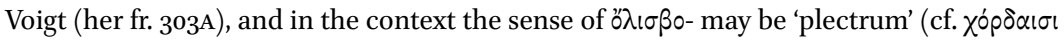
in line 4), cf. Yatromanolakis (2007) 251-254, Rayor and Lardinois (2014) 125-126. Fr. 189 = Phrynichus Ecloga 272 Fischer $=273$ Rutherford. 


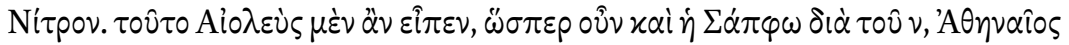

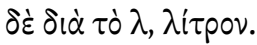

Nitron. This is what an Aeolian would have said, as indeed does Sappho, with a $n u$. But an Athenian would have said it with a lambda, litron.

Why is Charaxos bringing Sappho things she wants, some of them perhaps closely related to her activity as an entertainer, from Naucratis? To humour her? More likely, I would guess, we have traces of a coordinated family business. Charaxos exports wine from the family's estates to Naucratis, ${ }^{45}$ Larichus pours wine from these same estates in the prytaneion at Mytilene..$^{46}$ This activity of Larichus is often read together with a remark by a scholiast on the Iliad that

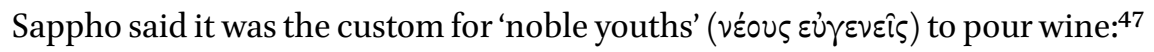
but without the context in which she said this-not necessarily the same poem as that to which Athenaeus refers-we cannot tell whether Larichus

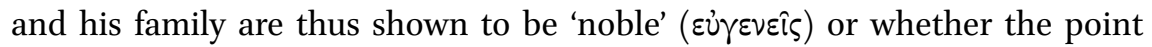

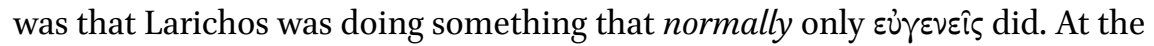
time of the new poem's composition Larichos seems to be still too young to fend for himself in a highly competitive adult male society, and his role in the prytaneion may be that not of a social equal but a social inferior. He may even be in the vulnerable position of the oinochooi on Attic vase-paintings, often naked, some of whom are clearly the passive objects of older men's sexual attention. $^{48}$

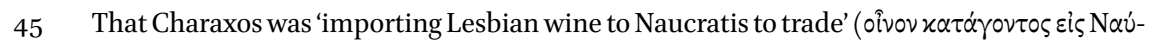

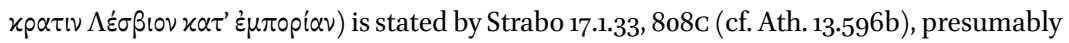
ultimately on the basis of what could be inferred from Sappho's poetry. Möller (2000) 55 suggests that Charaxos 'takes the surplus from his estates' and should be seen 'more as a traveller than as a trader'. I tend to accept in full Strabo's $\chi \alpha \tau^{\prime}$ ' $\xi \mu \pi \circ p^{\prime} \alpha v$ : without knowing the size of Charaxos' estate and the quality of its production we cannot judge whether he would have benefited his $\dot{\varepsilon} \mu \pi \circ \operatorname{pi}^{\alpha} \alpha$ by carrying other Mytileneans' wines as well as (or instead of) his own.

46 Test. 203 = Ath. 10.425a, attesting a poem in which Sappho praised Larichos in his capacity

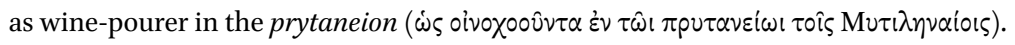

47 Schol. T on Iliad 20.234 (v 41 Erbse) = Sappho test. 203c.

48 For the problem of interpreting the status of oinochooi on Attic vases see Topper (2012) 53-85 (a chapter entitled 'Eros, Service and the Oinochoos'). For their possible sexual role, see Breitenberger (2007) 181-185. 


\section{Conclusions}

The first part of this paper stated the case for seeing the first context of performance of many of Sappho's songs as the male symposium, and for seeing Sappho herself as an outstanding singer to the accompaniment of a barbitos or lyra, a singer whose virtuosity was such that she was also in demand for performance at weddings and perhaps civic religious rituals. I then offered a discussion of how several well-known pieces of Sappho's poetry that involve expressions of desire, eros, might be understood on this hypothesis. Finally I turned to the 'Brothers Poem', suggesting that the complexity of the sequence in which the singer commands her female addressee to command her to pray for Charaxos' safe return justifies emendation of $\tilde{\varepsilon} \mu \varepsilon$ ('me') to $\varepsilon^{\prime} \mu \alpha$ ('my things'). The addressee will thus be the absent Doricha herself; the song will be testimony to Sappho's own interest in some of the cargo with which Charaxos was hoped to return from Egypt; and it will be one of a number of songs in which male symposiasts, some of them known to Charaxos and perhaps even seeing themselves as his comrades, $\dot{\tau}$ ¿îpol, were entertained by Sappho's expressions of loyalty to him and of her hostility to the entertainer in Naucratis who had led him astray. 